\title{
Front Matter: Volume 10042
}

, "Front Matter: Volume 10042," Proc. SPIE 10042, Diagnostic and

Therapeutic Applications of Light in Cardiology, 1004201 (12 April 2017); doi: $10.1117 / 12.2268488$

SPIE. Event: SPIE BiOS, 2017, San Francisco, California, United States 


\title{
Diagnostic and Therapeutic Applications of Light in Cardiology
}

\author{
Guillermo J. Tearney \\ Kenton W. Gregory \\ Laura Marcu \\ Editors
}

28-29 January 2017

San Francisco, California, United States

Sponsored and Published by

SPIE 
The papers included in this volume were part of the technical conference cited on the cover and title page. Papers were selected and subject to review by the editors and conference program committee. Some conference presentations may not be available for publication. The papers published in these proceedings reflect the work and thoughts of the authors and are published herein as submitted. The publisher is not responsible for the validity of the information or for any outcomes resulting from reliance thereon.

Please use the following format to cite material from these proceedings:

Author(s), "Title of Paper," in Diagnostic and Therapeutic Applications of Light in Cardiology, edited by Guillermo J. Tearney, Kenton W. Gregory, Laura Marcu, Proceedings of SPIE Vol. 10042 (SPIE, Bellingham, WA, 2017) Seven-digit Article CID Number.

ISSN: 1605-7422

ISSN: 2410-9045 (electronic)

ISBN: 9781510605251

ISBN: 9781510605268 (electronic)

Published by

SPIE

P.O. Box 10, Bellingham, Washington 98227-0010 USA

Telephone +1 3606763290 (Pacific Time) · Fax +1 3606471445

SPIE.org

Copyright (C) 2017, Society of Photo-Optical Instrumentation Engineers.

Copying of material in this book for internal or personal use, or for the internal or personal use of specific clients, beyond the fair use provisions granted by the U.S. Copyright Law is authorized by SPIE subject to payment of copying fees. The Transactional Reporting Service base fee for this volume is $\$ 18.00$ per article (or portion thereof), which should be paid directly to the Copyright Clearance Center (CCC), 222 Rosewood Drive, Danvers, MA 01923. Payment may also be made electronically through CCC Online at copyright.com. Other copying for republication, resale, advertising or promotion, or any form of systematic or multiple reproduction of any material in this book is prohibited except with permission in writing from the publisher. The CCC fee code is 1605 $7422 / 17 / \$ 18.00$.

Printed in the United States of America.

Publication of record for individual papers is online in the SPIE Digital Library.

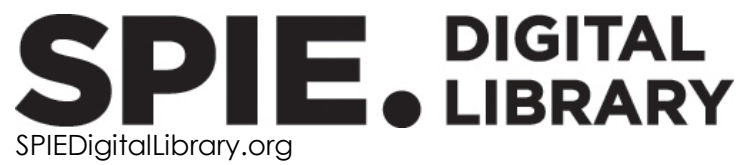

Paper Numbering: Proceedings of SPIE follow an e-First publication model, with papers published first online and then in print. Papers are published as they are submitted and meet publication criteria. A unique citation identifier (CID) number is assigned to each article at the time of the first publication. Utilization of CIDs allows articles to be fully citable as soon as they are published online, and connects the same identifier to all online, print, and electronic versions of the publication. SPIE uses a seven-digit CID article numbering system in which:

- The first five digits correspond to the SPIE volume number.

- The last two digits indicate publication order within the volume using a Base 36 numbering

system employing both numerals and letters. These two-number sets start with 00, 01, 02, 03, 04, $05,06,07,08,09,0 A, 0 B \ldots$. OZ, followed by 10-1Z, 20-2Z, etc.

The CID Number appears on each page of the manuscript. The complete citation is used on the first page, and an abbreviated version on subsequent pages. 


\title{
Contents
}

\author{
$\checkmark$ Authors \\ vii Conference Committee
}

\section{MYOCARDIUM}

1004202 Using molecular imaging to assess the delivery and infection of protease activated virus in animal model of myocardial infarction [10042-1]

1004203 Mapping the human atria with optical coherence tomography [10042-2]

1004205 Non-contact arrhythmia assessment in natural settings: a step toward preventive cardiac care [10042-4]

1004207 Characterization of ventricular endomyocardial tissue using optical coherence tomography [10042-6]

\section{INNOVATIVE TECHNIQUES}

10042 OD In-situ laser fenestration of endovascular stent-graft in abdominal aortic aneurysm repair (EVAR) [10042-12]

\section{SPECTROSCOPY}

1004200 Robust classification of contact orientation between tissue and an integrated spectroscopy and radiofrequency ablation catheter [10042-23]

$100420 Q \quad$ Ex-vivo UV autofluorescence imaging and fluorescence spectroscopy of atherosclerotic pathology in human aorta [10042-25] 
Proc. of SPIE Vol. 10042 1004201-4

Downloaded From: https://www.spiedigitallibrary.org/conference-proceedings-of-spie on 26 Apr 2023 Terms of Use: https://www.spiedigitallibrary.org/terms-of-use 


\title{
Authors
}

Numbers in the index correspond to the last two digits of the seven-digit citation identifier (CID) article numbering system used in Proceedings of SPIE. The first five digits reflect the volume number. Base 36 numbering is employed for the last two digits and indicates the order of articles within the volume. Numbers start with 00, 01, 02, 03, 04, 05, 06, 07, 08, 09, OA, OB...0Z, followed by 10-1Z, 20-2Z, etc.

\author{
Amelard, Robert, 05 \\ Clausi, David A., 05 \\ Condino, Sara, OD \\ Ferrari, Vincenzo, OD \\ Franco, Walfre, $\mathrm{OQ}$ \\ Gan, Yu, 03, 07 \\ Guenther, Caitlin, 02 \\ Hendon, Christine P., 03, 07, 00 \\ Hughson, Richard L., 05 \\ Kwon, Sunkuk, 02 \\ Lewis, William, $0 Q$ \\ Lye, Theresa H., 03 \\ Marboe, Charles C., 07 \\ Micheletti, Filippo, OD \\ Piazza, Roberta, OD \\ Pini, Roberto, OD \\ Rossi, Francesca, OD \\ Sevick-Muraca, Eva M., 02 \\ Singh-Moon, Rajinder P., 00 \\ Suh, Junghae, 02 \\ Tsay, David, 07 \\ Williams, Maura, $0 Q$ \\ Wong, Alexander, 05 \\ Yao, Xinwen, 07 \\ Zaryab, Mohammad, 00 \\ Zhu, Banghe, 02
}


Proc. of SPIE Vol. 10042 1004201-6

Downloaded From: https://www.spiedigitallibrary.org/conference-proceedings-of-spie on 26 Apr 2023 Terms of Use: https://www.spiedigitallibrary.org/terms-of-use 


\title{
Conference Committee
}

\author{
Symposium Chairs \\ James G. Fujimoto, Massachusetts Institute of Technology \\ (United States) \\ R. Rox Anderson, Wellman Center for Photomedicine, Massachusetts \\ General Hospital (United States) and Harvard School of Medicine \\ (United States)
}

Program Track Chair:

Brian Jet-Fei Wong, Beckman Laser Institute and Medical Clinic (United States)

Conference Chairs

Guillermo J. Tearney, Wellman Center for Photomedicine (United States)

Kenton W. Gregory, Oregon Medical Laser Center

(United States)

Laura Marcu, University of California, Davis (United States)

Conference Program Committee

Gijs van Soest, Erasmus MC (Netherlands)

Carlo Di Mario, University College London (United Kingdom)

Stanislav Y. Emelianov, The University of Texas at Austin (United States)

Session Chairs

1 Myocardium

Christine P. Hendon, Columbia University (United States)

2 Multimodality Imaging

Guillermo J. Tearney, Wellman Center for Photomedicine (United States)

3 Innovative Techniques

Kenton W. Gregory, Oregon Medical Laser Center

(United States)

4 Optical Coherence Tomography

Guillermo J. Tearney, Wellman Center for Photomedicine

(United States) 


\section{Spectroscopy}

Laura Marcu, University of California, Davis (United States)

Proc. of SPIE Vol. 10042 1004201-8

Downloaded From: https://www.spiedigitallibrary.org/conference-proceedings-of-spie on 26 Apr 2023 Terms of Use: https://www.spiedigitallibrary.org/terms-of-use 